\title{
ENHANCED CORROSION RESISTANCE OF A CHROMIUM-FREE CONVERSION/ORGANIC COMPOSITE COATING ON AN AZ91D MAGNESIUM ALLOY
}

\section{IZBOLJŠANJE KOROZIJSKE OBSTOJNOSTI Mg ZLITINE AZ91D S KONVERZIJSKO/ORGANSKO KOMPOZITNO PREVLEKO BREZ Cr}

\author{
Guihong Geng ${ }^{1}$, Dongxin Wang ${ }^{2}$, Lei Zhang ${ }^{1}$, Weiye Chen ${ }^{1}$, Zhijie Yan ${ }^{1,3 *}$, Guiqun Liu ${ }^{1}$ \\ ${ }^{1}$ North Minzu University, School of Materials Science and Engineering, no. 204 Wenchang North Street, Xixia District, \\ Yinchuan 750021, P. R. China \\ ${ }^{2}$ Northwest Rare Metal Materials Research Institute Ningxia Co., Ltd., State Key Laboratory of Special Rare Metal Materials, no. 119 Yejin \\ Road, Dawukou District, Shizuishan 753000, P. R. China \\ ${ }^{3}$ North University of China, School of Materials Science and Engineering, no. 3 Xueyuan Road, Jiancaoping District, \\ Taiyuan 030051, P. R. China
}

Prejem rokopisa - received: 2018-08-10; sprejem za objavo - accepted for publication: 2018-11-22

doi:10.17222/mit.2018.176

A composite coating was prepared on an AZ91D magnesium alloy; first, a chromium-free potassium permanganate conversion substrate was deposited and then the substrate was further coated with epoxy resins. The surface morphology, chemical composition and deposited products of the conversion coating were investigated with scanning electron microscopy (SEM), energy dispersive spectroscopy (EDS) and X-ray diffraction (XRD). The results show that the conversion coating mainly consists of $\mathrm{MnO}_{2}$ and $\mathrm{Al}_{2} \mathrm{O}_{3}$ oxides, whose Pilling-Bedworth ratios (PBR) are larger than 1, indicating that the conversion coating is dense. Electrochemical-impedance-spectroscopy (EIS) plots reveal that the conversion coating shows a strong resistance to the flow of ions and electrons, demonstrating that the corrosion resistance of the AZ91D magnesium alloy is considerably enhanced Neutral salt spray tests show that the corrosion resistance of the AZ91D magnesium alloy is substantially improved due to a composite coating consisting of a conversion deposit and an organic coating.

Keywords: corrosion resistance, chromium-free coating, magnesium alloys

Avtorji so pripravili kompozitno prevleko na površini Mg zlitine AZ91D, tako da so najprej nanesli na površino zlitine konverzijski substrat (nanos) iz kalijevega permanganata brez $\mathrm{Cr}$, nato pa ga prevlekli še z epoksi smolo. Površinsko morfologijo, kemijsko sestavo in nanešene produkte konverzijske prevleke so nato preiskovali z vrstično elektronsko mikroskopijo (SEM), energijsko disperzijsko spektroskopijo (EDS) in rentgensko difrakcijo (XRD). Rezultati raziskave so pokazali, da prevleka v glavnem vsebuje $\mathrm{MnO}_{2}$ in $\mathrm{Al}_{2} \mathrm{O}_{3}$. Vrednosti za Pilling-Bedworthovo razmerje (PBR) so večje kot 1 , kar kaže na to, da je izdelana prevleka dobro zgoščena (brez por). Elektrokemična impedančna spektroskopija (EIS) je pokazala, da ima izdelana prevleka močno odpornost proti toku ionov in elektronov. To potrjuje, da je korozijska obstojnost Mg zlitine AZ91D močno izboljšana. Preizkus s sprejem naravne soli je pokazal, da je korozijska odpornost Mg zlitine AZ91D znatno izboljšana zaradi nanosa kompozitne prevleke, sestavljene iz konverzijskega nanosa in organske prevleke.

Ključne besede: odpornost proti koroziji, prevleke brez kroma, kemična pretvorba, zlitina na osnovi magnezija

\section{INTRODUCTION}

Magnesium alloys exhibit several advantageous properties, including low densities, high strength-to-weight ratio, high stiffness and good recyclability; consequently, they are promising potential applications in the automotive and aerospace industries. ${ }^{1,2}$ However, the poor corrosion resistance of magnesium alloys strongly limits their engineering applications. An effective way to prevent the corrosion of magnesium alloys is coating. Various coating techniques such as chemical conversion coatings, ${ }^{3-8}$ ceramic coatings, ${ }^{9}$ electro- or electroless metal plating, ${ }^{10}$ anodizing, ${ }^{11}$ superhydrophobic coatings ${ }^{12}$ and sputtering deposition processes, ${ }^{13,14}$ have been developed to improve the corrosion resistance of magnesium

*Corresponding author e-mail:

zjyan@nuc.edu.cn alloys. Among them, conversion coatings are common surface-protective methods, improving the corrosion resistance of magnesium alloys. They are produced with a chemical or electrochemical treatment of metal surfaces, forming superficial layers of the substrate that are chemically bonded to the surface.

In the traditional conversion technique, the coatings based on compounds with hexavalent chromium $\left(\mathrm{Cr}^{6+}\right)$ are widely used to protect magnesium alloys. ${ }^{15}$ However, the increasing safety concerns regarding highly toxic chromate compound push researchers to develop chromate-free conversion-coating methods. In recent years, it has been reported that phosphate-permanganate conversion coatings effectively improve the corrosion resistance of magnesium alloys, which are environmentally friendly and have been shown to have similar effects on the corrosion resistance as the chromate conversion 
coatings. ${ }^{16-20}$ However, it was found that there are non-penetrating micro-cracks on the phosphate and permanganate conversion coatings, ${ }^{19,20}$ which considerably deteriorate the corrosion resistance of the coatings. To further improve the corrosion resistance of conversion coatings, direct exposure of the non-penetrating microcracks in corrosive media should be avoided. Moreover, polymeric coatings are found to considerably improve the corrosion resistance of magnesium alloys. ${ }^{21,22}$ Based on these considerations, in the present work, a potassium permanganate conversion substrate was first deposited on the AZ91D magnesium alloy and the conversion coating was subsequently covered with environmentallyfriendly epoxy resins. The corrosion resistance of the prepared composite coating, composed of a conversion substrate and an organic coating, was investigated.

\section{EXPERIMENTAL PART}

Samples of a commercial AZ91D magnesium alloy (9.27 Al, 0.25 Zn, 0.35 Mn, and balanced $\mathrm{Mg}$, all in mass fractions, $w / \%)$ with dimensions of $(10 \times 10 \times 10)$ $\mathrm{mm}$ were prepared for electrochemical impedance spectroscopies (EIS) and immersion tests. Samples with dimensions of $(30 \times 30 \times 5) \mathrm{mm}$ were prepared for adhesion tests and salt-spray tests. It is very important for a magnesium alloy to conduct a surface pretreatment prior to the chemical conversion since its surface plays a critical role in a chemical-conversion process. Here, the surfaces of the samples were metallographically ground using 600-1200 grit silicon carbide papers, rinsed with deionized water, ultrasonically degreased in acetone for $30 \mathrm{~min}$ and then dried with warm air.

After the surface pretreatments, a chemical conversion was carried out by immersing the samples into a mixture solution of $\mathrm{KMnO}_{4}(20 \mathrm{~g} / \mathrm{L})$ and $\mathrm{Mn}\left(\mathrm{H}_{2} \mathrm{PO}_{4}\right)_{2}$ (60 g/L) for 8-9 min at 323-333 K. After the conversion deposition, the samples were cleaned in distilled water and then dried. Later, epoxy resins were applied onto the conversion substrates. Finally, the samples coated with epoxy resins were dried by keeping them in an incubator at $333 \mathrm{~K}$ for $72 \mathrm{~h}$.

The morphologies and compositions of the conversion coatings were investigated with scanning electron microscopy (SEM, Hitachi S4800) and energy dispersive spectroscopy (EDS, Thermo Scientific Noran System 7). The products deposited during the conversion treatments were identified with $\mathrm{X}$-ray diffraction (XRD, X' TRA) using monochromatic $\mathrm{Cu}-K_{\alpha}$ radiation. The thickness of the conversion coating was measured with 3D digital microscopy (DM, VHX-600), with which the thickness profile of the conversion coating was obtained. The corrosion resistance of the samples was evaluated after their immersion in a neutral solution of $3.5 w / \% \mathrm{NaCl}$ for $132 \mathrm{~h}$ at room temperature. The EIS tests of the conversion coatings were conducted under a three-electrode system using the Autolab PGSTAT 302 electrochemical measurement system. The samples served as the working electrodes and the saturated calomel electrode acted as the reference electrode together with a platinum counter electrode. Before the electrochemical tests, the samples covered with conversion coatings were exposed to a solution of $5 w / \% \mathrm{NaCl}$ in an electrolytic cell at their open circuit potentials (OCP) for $10 \mathrm{~min}$. The cross-cut method was employed to evaluate the adhesion strength of the organic coating onto the conversion coating according to the ISO 2409 standard. ${ }^{23}$ The cut flaws of the organic coating were observed after the cut actions. An adhesive cellophane tape was pasted onto the cut flaws and then the tape was peeled off them to evaluate the adhesion strength of the organic coating. ${ }^{24}$ According to the ASTM B117.97 standard, ${ }^{25}$ the samples covered with organic coatings were subjected to a salt-spray test to investigate their anti-corrosion properties. A salt-spray cabinet (model ZY8200) was used for the salt-spray tests.

\section{RESULTS AND DISCUSSION}

\subsection{Morphology and composition of a conversion coat- ing}

The macromorphology of a conversion coating on the AZ91D magnesium alloy is presented in Figure 1a. It is seen that a yellow brown conversion coating was deposited after the potassium permanganate conversion treatment. A SEM image and an EDS spectrum of the conversion coating are shown in Figures $\mathbf{1 b}$ and 1c, respectively. It is obvious that there are reticular microcracks in the conversion coating (Figure 1b). The inhomogeneous electrochemical property of the AZ91D magnesium alloy may lead to a formation of abundant micro-batteries on the surface of the alloy in the conversion solution. As a result, electrochemical corrosion occurs during the conversion treatment, in which the $\alpha-\mathrm{Mg}$ matrix phase acts as the anode and the intermetallic $\beta-\mathrm{Mg}_{17} \mathrm{Al}_{12}$ phase as the cathode since the corrosion potential of $\mathrm{Mg}$ is lower than that of $\mathrm{Mg}_{17} \mathrm{Al}_{12} \cdot{ }^{26}$ The

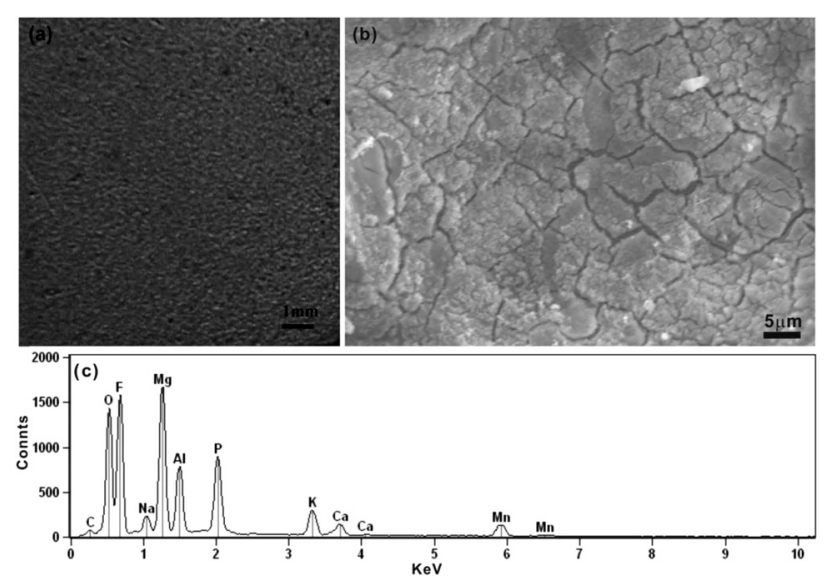

Figure 1: a) Macromorphology, b) SEM image and c) EDS spectrum of a conversion coating deposited on AZ91D magnesium alloy 

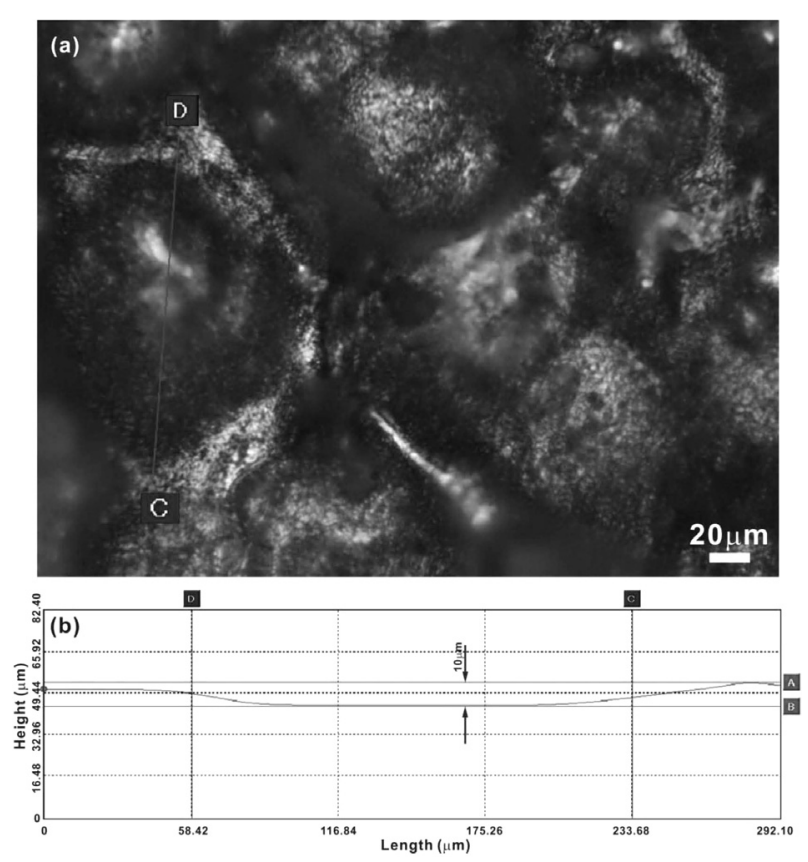

Figure 2: a) DM image of a conversion coating and b) the corresponding line scanning profile from point $\mathrm{C}$ to point $\mathrm{D}$

conversion reaction first takes place in the micro-cathode area, leading to hydrogen corrosion. Subsequently, the deposited products nucleate and grow onto the $\beta$ phase. With the accumulation of deposits, a uniform conversion coating gradually forms on the surface of the AZ91D magnesium alloy. The hydrogen precipitation in the process of the conversion reaction results in an explosion force during the micro-bubbles floating, which is believed to contribute to the microcracks on the conversion coating. Compared to the previously prepared conversion coatings, ${ }^{27}$ the emergence of microcracks roughens the coating surface, providing a good substrate for the subsequent organic coating. This morphology characteristic of the conversion coating is beneficial for the improvement of the adhesion strength of the organic coating on the substrate and it will be discussed later.

An EDS spectrum of the conversion coating indicates that the conversion coating is mainly composed of $\mathrm{F}, \mathrm{Mg}$, $\mathrm{Al}$, O, P and Mn (Figure 1c). The element of F originates from the hydrofluoric acid pickling in the process of pretreatment, and the elements of $\mathrm{Mg}$ and $\mathrm{Al}$ come from the chemical and electrochemical reactions of the magnesium alloy in the permanganate solution, during which these elements dissolved into the conversion coating. Figure 2 presents a DM image of a conversion coating. The line scanning profile from point $\mathrm{C}$ to point $\mathrm{D}$ in Figure 2a is shown in Figure 2b. It shows that the thickness of the conversion coating is approximately 9-10 $\mu \mathrm{m}$ and its thickness is uniform, which indicates that the chemical-conversion reaction occurred homogeneously on the alloy surface.

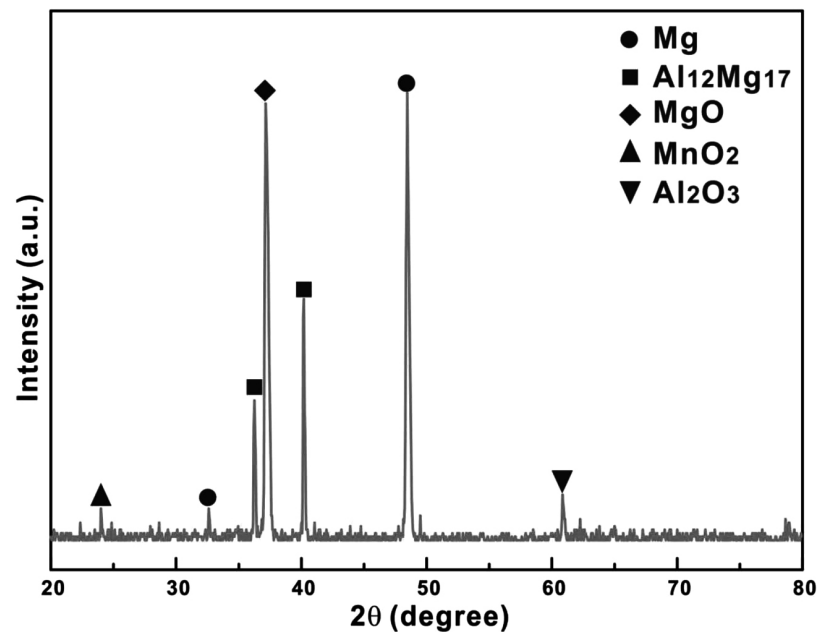

Figure 3: XRD pattern of a conversion coating deposited on AZ91D magnesium alloy

\subsection{Products of a conversion coating}

The XRD pattern of a conversion coating is shown in Figure 3. Since X-rays can penetrate a thickness of about $100 \mu \mathrm{m},{ }^{27}$ the sharp peaks of the XRD pattern in Figure 3 originate from both the AZ91D magnesium alloy and the conversion coating (with a thickness of about 9-10 $\mu \mathrm{m}$ ). The AZ91 magnesium alloy mainly consists of an $\alpha-\mathrm{Mg}$ matrix phase and intermetallic $\beta-\mathrm{Mg}_{17} \mathrm{Al}_{12}$ phase. As a result, the products of the conversion coating are composed of $\mathrm{MgO}, \mathrm{MnO}_{2}, \mathrm{Al}_{2} \mathrm{O}_{3}$ and some other unidentified phases. From the XRD pattern, it is concluded that the conversion coating mainly consists of oxides, which determine the corrosion resistance of the magnesium alloy.

\subsection{Corrosion resistance of a conversion coating}

The morphologies of the samples after full-immersion tests are shown in Figure 4. The corrosion morphology of a sample with a conversion coating is shown in Figure 4a. For comparison, the corrosion morphology of the AZ91D magnesium alloy without the conversion treatment is also shown in Figure 4b. From Figure 4, it is clear that the alloy without a conversion treatment corrodes seriously and abundant corrosion holes appear on the surface (Figure 4b). On the other hand, a mild corrosion occurs on the surface of the alloy with a conversion coating (Figure 4a). From the results of the full-immersion tests, it is clear that the annual corrosion rates of the AZ91D magnesium alloy before and after the conversion treatment are $11.36 \mathrm{~mm} / \mathrm{a}$ and $1.35 \mathrm{~mm} / \mathrm{a}$, respectively. This suggests that the corrosion resistance of the AZ91D magnesium alloy is considerably improved due to the formation of a conversion coating.

The corrosion resistance of a conversion coating depends on its value of the Pilling-Bedworth ratio (PBR, the ratio of the volume of the elementary cell of a metal 


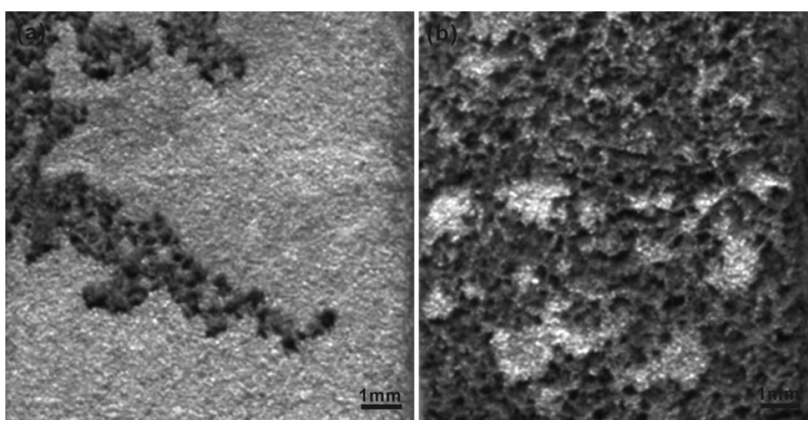

Figure 4: Corrosion morphologies of the samples: a) with a conversion coating and b) without conversion treatment

oxide to the volume of the elementary cell of the corresponding metal). When the value of $\mathrm{PBR}<1$, the coating is porous and easily subjected to corrosion. When the value of PBR $>1$, the coating is dense and shows favorable corrosion resistance. Based on the XRD pattern from Figure 3, the conversion coating mainly consists of dense $\mathrm{MnO}_{2} \quad(\mathrm{PBR}=1.77)$ and $\mathrm{Al}_{2} \mathrm{O}_{3}$ ( $\mathrm{PBR}=1.28)$, which mainly substitute the porous magnesium oxide $\mathrm{MgO}(\mathrm{PBR}=0.81) .{ }^{28}$ As a result, a dense oxide coating covers the magnesium matrix, which substantially improves the corrosion resistance. It can be concluded that the considerable improvement of the corrosion resistance of the AZ91D magnesium alloy is due to the formation of a passivated and dense oxide coating, whose PBR value is considerably larger than 1 . This is verified with the EIS data, which is discussed in section 3.4.

\subsection{EIS plots of the magnesium AZ91D alloy with a conversion coating}

The EIS plots of a sample with a conversion coating are shown in Figures 5a and $\mathbf{5 b}$. The low frequency impedance in the Bode plot monotonously increases as the frequency drops (Figure 5a), indicating a strong resistance of the conversion coatings to the flow of ions and electrons. As a result, the corrosion resistance is enhanced. The Nyquist plot is shown in Figure 5b. The Nyquist plot exhibits two loops, which reveal that the corrosion first occurs on the conversion coating and then on the matrix. This indicates that the existence of the conversion coating prevents the corrosion from occurring directly on the matrix, which enhances the corrosion resistance. The equivalent circuit proposed for fitting the EIS data is shown in Figure 5c. In the equivalent circuit, $R_{\mathrm{s}}, R_{\mathrm{p}}, R_{\mathrm{t}}$ and $C_{\mathrm{d}}$ represent the solution resistance between the reference electrode and the working electrode, polarization resistance, the charge-transfer resistance and the electric double-layer capacitor, respectively. The constant phase angle element (CPE) is used to replace the pure capacitance element to reflect the dispersion effect due to the roughness of the electrode interface. The EIS results agree with the equivalent circuit.

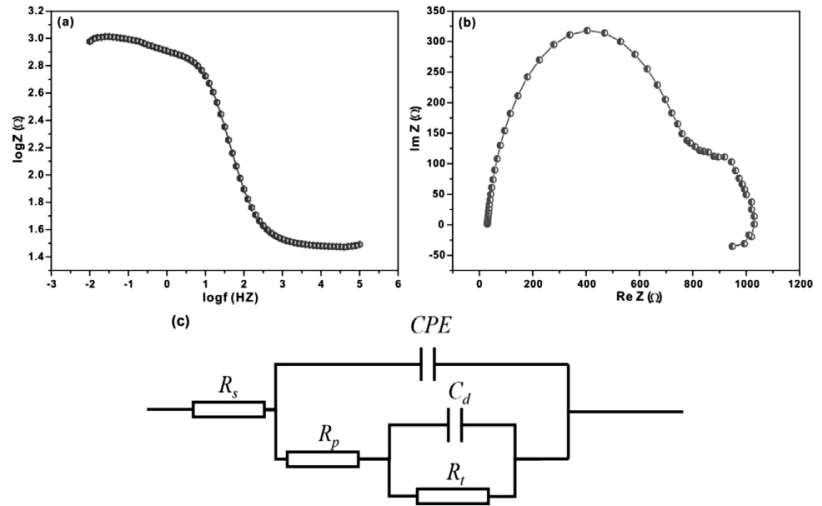

Figure 5: a) EIS Bode plot and b) Nyquist plot of the converted AZ91D magnesium alloy in a $5 \mathrm{w} / \% \mathrm{NaCl}$ solution, and c) the equivalent circuit for fitting the EIS data

\subsection{Adhesion strength of an organic coating}

The adhesion-strength tests according to the ISO 2049 standard were introduced to evaluate the adhesion strength of the organic coatings. For comparison, the adhesion strength of an organic coating on the AZ91D magnesium alloy without a conversion coating is also investigated as a reference. The surface of the AZ91Dmagnesium-alloy sample was treated with shot blasting before the application of the organic coating and then epoxy resins were directly deposited on its surface.

According to standard ISO 204923, the adhesion strength of the coating is evaluated in terms of its falling off the substrate. The morphologies of scratch patterns are shown in Figure 6, indicating that the cohesion force of the organic coating on the conversion substrate is much stronger than that on the sample without a conversion coating. The adhesion-strength grades of the organic coating on the samples with and without a conversion coating were evaluated to be 1 (Figure 6a) and 3 (Figure 6b), respectively. The conversion coating is an alkaline material, and the epoxy coating is neutral or alkaline. This is favorable for the cohesion between the organic coating and the conversion coating, resulting in a much better adhesion strength. Furthermore, the epoxy resin invades into the pre-existing microcracks of the conversion coating. During the subsequent constant
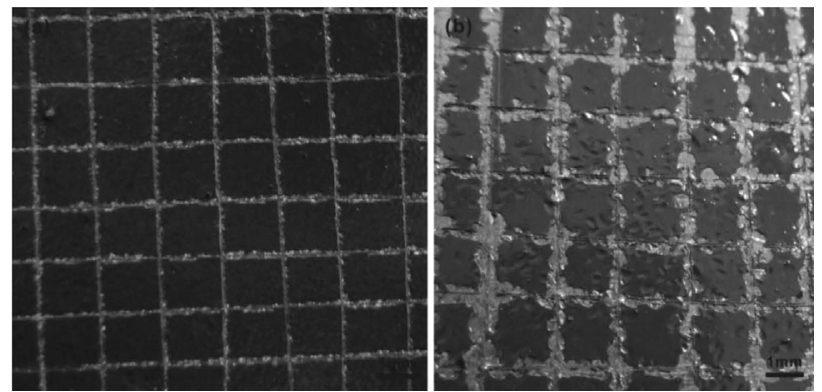

Figure 6: Surface morphologies of the scratched patterns on the organic coatings on the surfaces of AZ91D magnesium alloy samples a) with and b) without a conversion coating 
high-temperature condition, the mutual penetration and diffusion between the epoxy resin and conversion coating result in a mutual tolerance and synergistic effects, which enhance the adhesion strength. On the other hand, on the sample without a conversion coating, there is just a mechanical combination between the organic coating and the metal substrate. As a result, the organic coating is not well attached onto the surface of the sample without a conversion coating and the organic coating flakes off easily under an external force.

\subsection{Corrosion resistance of the organic coating on a conversion substrate}

Figure 7a shows the corrosion morphology of a converted sample after its immersion in a solution of $3.5 \mathrm{w} / \%$ $\mathrm{NaCl}$ for two and five days at room temperature. It is found that there is a small quantity of corrosion spots on the surface of the converted sample after two days of the immersion. After five days of immersion in the $\mathrm{NaCl}$ solution, the sample without an organic coating is considerably damaged (bottom side in Figure 7a). Figure $\mathbf{7 b}$ shows the corrosion morphology of a sample with a composite coating consisting of the organic coating on the precursor conversion substrate under a neutral salt spray of $3.5 w / \% \mathrm{NaCl}$ for five days. It is clear that there is little damage on the surface of the organic coating on the conversion coating.

It is worth noting that the salt spray is much more corrosive than a solution with the same concentration of $\mathrm{NaCl}$. The organic coating on the conversion substrate shows a better corrosion resistance under a spray than that without an organic coating, fully immersed in the solution. Based on the facts above, it can be concluded that the corrosion resistance is greatly improved due to the application of an organic coating on the conversion coating. The conversion coating provides an adhesive and rough substrate for the subsequent organic coating, and the organic substances penetrate into the microcracks of the conversion coating, leading to a formation of a dense composite coating. As a result, the organic coating prevents the conversion coating from direct

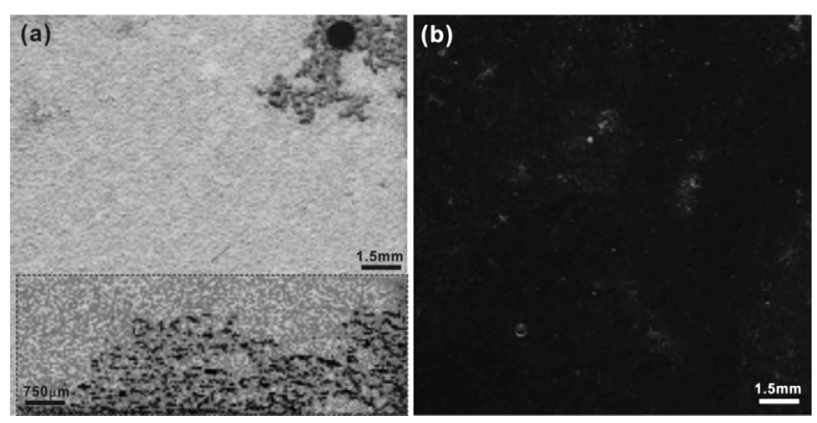

Figure 7: Corrosion morphologies of the sample with a conversion coating after immersion in a solution of $3.5 \mathrm{w} / \% \mathrm{NaCl}$ for two days (upper side) and five days (lower side) a) and the sample with an organic coating applied onto the conversion substrate under a neutral salt spray of $3.5 \mathrm{w} / \% \mathrm{NaCl}$ for five days b) exposure to the etching media, which further enhances the corrosion resistance.

\section{CONCLUSIONS}

(1) A uniform and dense conversion coating is deposited on AZ91D magnesium using a chemical-conversion treatment in a potassium permanganate solution, and abundant reticular microcracks are found on the surface of the conversion coating. The main elements of the conversion coating are $\mathrm{F}, \mathrm{Mg}, \mathrm{Al}, \mathrm{O}, \mathrm{P}$ and $\mathrm{Mn}$. The phase products of the conversion coating mainly include oxides $\mathrm{MgO}, \mathrm{MnO}_{2}$ and $\mathrm{Al}_{2} \mathrm{O}_{3}$.

(2) EIS plots reveal a strong resistance of the conversion coating to the flow of ions and electrons, considerably preventing the corrosion of the AZ91D magnesium alloy, which is further verified with immersion tests. The improvement of the corrosion resistance of the alloy due to the conversion treatment is attributed to the formation of a dense conversion coating, mainly consisting of oxides $\mathrm{MnO}_{2}$ and $\mathrm{Al}_{2} \mathrm{O}_{3}$, whose PBR values are considerably larger than 1 .

(3) The application of an organic coating onto the conversion substrate prevents the conversion coating from direct exposure to erosive media, which further substantially enhances the corrosion resistance of the AZ91D magnesium alloy.

\section{Acknowledgements}

This project was financially supported by the National Natural Science Foundation of China (Grant no. 51561001) and State Key Laboratory of Special Rare Metal Materials.

\section{REFERENCES}

${ }^{1}$ J. E. Gray, B. Luan, Protective coatings on magnesium and its alloys - a critical review, J. Alloys Compd., 336 (2002), 88

${ }^{2}$ Y. Ali, D. Qiu, B. Jiang, F. Pan, M. X. Zhang, Current research progress in grain refinement of cast magnesium alloys: A review article, J. Alloys Compd., 619 (2015), 639

${ }^{3}$ T. Ishizaki, N. Kamiyama, K. Watanabe, A. Serizawa, Corrosion resistance of $\mathrm{Mg}(\mathrm{OH})(2) / \mathrm{Mg}-\mathrm{Al}$ layered double hydroxide composite film formed directly on combustion-resistant magnesium alloy AMCa602 by steam coating, Corros. Sci., 92 (2015), 76

${ }^{4}$ C. D. Gu, W. Yan, J. L. Zhang, J. P. Tu, Corrosion resistance of AZ31B magnesium alloy with a conversion coating produced from a choline chloride-urea based deep eutectic solvent, Corros. Sci., 106 (2016), 108

${ }^{5}$ X. Li, Z. Y. Weng, W. Yuan, X. Z. Luo, H. M. Wong, X. M. Liu, S. L. Wu, K. W. K. Yeung, Y. F. Zheng, P. K. Chu, Corrosion resistance of dicalcium phosphate dihydrate/poly(lactic-co-glycolic acid) hybrid coating on AZ31 magnesium alloy, Corros. Sci., 102 (2016), 209

${ }^{6}$ L. J. Zhang, E. A. A. Mohammed, A. Adriaens, Synthesis and electrochemical behavior of a magnesium fluoride-polydopamine-stearic acid composite coating on AZ31 magnesium alloy, Surf. Coat. Tech., 307 (2016), 56 
${ }^{7}$ Z. J. Li, Y. Yuan, X. Y. Jing, Composite coatings prepared by combined plasma electrolytic oxidation and chemical conversion routes on magnesium-lithium alloy, J. Alloys Compd., 706 (2017), 419

${ }^{8} \mathrm{~S}$. Nezamdoust, D. Seifzadeh, Application of Ce-V/sol-gel composite coating for corrosion protection of AM60B magnesium alloy, Nonferrous Met. Soc. China, 27 (2017), 352

${ }^{9}$ S. B. Hassen, L. Bousselmi, P. Bercot, M. E. Rezrazi, E. Triki, XPS characterization and corrosion resistance of cerium-treated magnesium coatings, Rare Metals, 30 (2011), 368

${ }^{10}$ C. D. Gu, J. S. Lian, G. Y. Li, L. Y. Niu, Z. H. Jiang, Electroless Ni-P plating on AZ91D magnesium alloy from a sulfate solution, J. Alloys Compd., 391 (2005), 104

${ }^{11}$ M. C. L. De Oliveria, V. S. M. Pereira, O. V. Correa, A. Antunes, Corrosion performance of anodized AZ91D magnesium alloy: effect of the anodizing potential on the film structure and corrosion behavior, J. Mater. Eng. Perform., 23 (2013), 593

${ }^{12}$ D. Zang, R. Zhu, W. Zhang, J. Wu, X. Yu, Y. Zhang, Stearic acid modified aluminum surfaces with controlled wetting properties and corrosion resistance, Corros. Sci., 83 (2014), 86

${ }^{13}$ H. W. Huo, Y. Li, F. H. Wang, Improvement on the corrosion resistance of AZ91D magnesium alloy by aluminum diffusion coating, J. Mater. Sci. Technol., 23 (2007), 379

${ }^{14}$ S. K. Wu, S. C. Yen, T. S. Chou, A study of r.f.-sputtered Al and Ni thin films on AZ91D magnesium alloy, Surf. Coat. Tech., 200 (2006), 2769

${ }^{15}$ M. Aveddsian, H. Baker, Magnesium and magnesium alloys, ASM Specialty Handbook, ASM, Metals Park, Ohio, 1999

${ }^{16}$ S. Y. Jian, Y. R. Chu, C. S. Lin, Permanganate conversion coating on AZ31 magnesium alloys with enhanced corrosion resistance, Corros. Sci., 93 (2015), 301

${ }^{17}$ C. Y. Wu, J. Zhang, State-of-art on corrosion and protection of magnesium alloys based on patent literatures, Trans. Nonferrous Met. Soc. China, 21 (2011), 892
${ }^{18}$ Y. L. Cheng, H. L. Wu, Z. H. Chen, H. M. Wang, L. L. Li, Phosphating process of AZ31 magnesium alloy and corrosion resistance of coatings, Trans. Nonferrous Met. Soc. China, 16 (2006), 1086

${ }^{19}$ M. Zhao, S. S. Wu, J. R. Luo, Y. Fukuda, H. Nakae, A chromiumfree conversion coating of magnesium alloy by a phosphate-permanganate solution, Surf. Coat. Tech., 200 (2006), 5407

${ }^{20}$ K. Z. Chong, T. S. Shih, Conversion-coating treatment for magnesium alloys by a permanganate-phosphate solution, Mater. Chem. Phys., 80 (2003), 191

${ }^{21}$ A. Zomorodian, M. P. Garcia, E. Moura, T. Silva, J. C. S. Fernandes, M. H. Fernades, M. F. Montemor, Corrosion resistance of a composite polymeric coating applied on biodegradable AZ31 magnesium alloy, Acta Biomater., 9 (2013), 8660

${ }^{22}$ X. L. He, Y. H. Wei, L. F. Hou, Z. F. Yan, C. L. Guo, P. J. Han, Corrosion fatigue behavior of epoxy-coated $\mathrm{Mg}-3 \mathrm{Al}-1 \mathrm{Zn}$ alloy in $\mathrm{NaCl}$ solution, Rare Metals, 33 (2014), 276

${ }^{23}$ ISO 2409:2007 (E) - Paints and Varnishes, Cross-Cut Test. CEN, Brussels, Belgium

${ }^{24}$ JIS K5400:1990 (E) - Japanese Industrial Standard Testing Methods for Paints, Japanese Standards Association, Tokyo, Japan

${ }^{25}$ ASTM Designation B117-97:1997 (E) - ASTM, Philadelphia

${ }^{26}$ S. Candan, M. Unal, E. Koc, Y. Turen, E. Candan, Effects of titanium addition on mechanical and corrosion behaviours of AZ91 magnesium alloy, J. Alloys Compd., 509 (2011), 1958

${ }^{27}$ H. H. Elsentriecy, K. Azumi, H. Konno, Improvement in stannate chemical conversion coatings on AZ91D magnesium alloy using the potentiostatic technique, Electrochim. Acta, 53 (2007), 1006

${ }^{28}$ M. Syvertsen, K. Aarstad, G. Trancell, T. A. Engh, in: K. U. Kainer (Ed.), Magnesium: Proceedings of 7th International Conference on Magnesium Alloys and their Applications, 2006 